\title{
Circulating Microvesicles in Regenerative Angiogenesis
}

\author{
Droźdż A and Stępień E* \\ Department of Medical Physics, Jagiellonian University, Poland
}

Submission: April 04, 2017; Published: April 10, 2017

"Corresponding author: Ewa Stępień, Zakład Fizyki Medycznej, Instytut Fizyki im. Mariana Smoluchowskiego, Uniwersytet Jagielloński, ul. S. Łojasiewicza 11, 30-348 Kraków, Polska, Poland, Tel: +48 1266447 62; Email: e.stepien@uj.edu.pl

\begin{abstract}
Extracellular microvesicles (EVs) released by different cells have been shown to facilitate the transfer of several pro-angiogenic as well as anti-antigenic factors that can regulate gene expression in endothelial cells. Our recent study has demonstrated that the profiles of cytokines and angiogenic-active factors in EVs are significantly changed in patients with diabetes that can act both pro-and anti-proliferative. We suggest that those factors may facilitate vascular regeneration and angiogenesis.

Keywords: Angiogenesis; Ectosomes; Exosomes; Microparticles; MicroRNA; Regeneration; Vessels

Abbreviations: CAD: Coronary Artery Disease; Cryo-TEM: Cryogenic Transmission Electron Microscopy; DAT-Mscs: Type 2 Diabeticadipose Tissue-Derived Mesenchymal Stem Cells; EC:Ectosomes; Evs: Extracellular Vesicles; Ex: Exosomes; MVB: Multivesicular Bodies; MSC: Mesenchymal Stem Cells; NAT-Mscs: Non-Diabetic Adipose Tissue-Derived Mesenchymal Stem Cells; TEM: Transmission Electron Microscopy
\end{abstract}

\section{What are Extracellular Microvesicles}

Extracellular microvesicles (EVs) are cell-derived membrane fragments of granules generated by most eukaryotic cells. Most commonly used transmission electron microscopy visualization allowed to determine their diameter between $50 \mathrm{~nm}$ and 1000 $\mathrm{nm}$. Despite the small size, their presence in blood was firstly reported using flow cytometry method in late 60 's by Wolf, who suggested that the lipid-rich particles originated from the osmophilic platelet granules ("platelet dust") have a thrombotic potential [1]. Previously, George E. Palade's transmission electron microscopy (TEM) studies on segregation of ferritin showed a number of membrane structure budded to the capillary lumen involved in protein transport [2]. In the second half of the 70's - the last century they were alongside reported in cancer cell lines [3]. It has been commonly accepted that EVs can be produced in two alternative ways: 1 . by budding or peeling of cell membrane fragments erasing as cell protrusions by a calcium-depending mechanism - this population of EVs is called ectosomes (Ect); 2. by a fusion of multivesicular bodies (MVB) with the cell membrane and subsequent exocytosis-exosomes (Ex) [4]. Generally, this classification is based on the release mechanism criteria, while the size, density and cellular origin determine their taxonomy: Ect represent rather heterogeneous population of vesicles whose size ranges from 0,1 to $1 \mu \mathrm{m}$ in diameter, Ex are smaller in size ranging 50-100nm [5] (Figure 1).

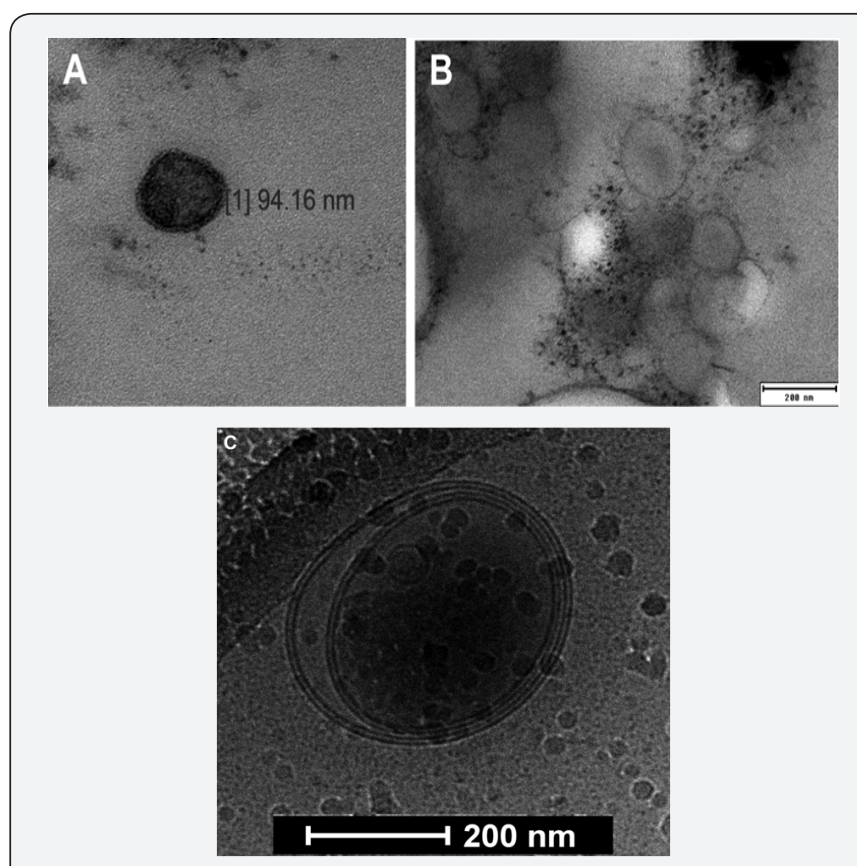

Figure 1: Images of extracellular vesicles (EVs) in EV-enriched fraction of human plasma samples. Transmission electron microscopy (TEM) visualization of exosome (A) and ectosome (B). Cryogenic transmission electron microscopy (Cryo-TEM) image of ectosome. 
Microscopically, EVs consist of cell components including a lipid bilayer, cytoplasm and ribosomal fragments. On their surface a number of phospholipids and transmembrane proteins can be detected, which can mark the cell origin and regulate their biological activity [6].

\section{Circulating EVs are Abundant in Body Fluids}

EVs are commonly present in a wide spectrum of body fluids such as blood (plasma), urine, saliva, breast milk, amniotic fluid, cerebrospinal fluid or semen. In different cardiovascular diseases including: coronary artery disease (CAD), myocardial infarction, stroke cardiomyopathy, hypertension and diabetes and thrombosis, EVs are treated as potential biomarkers of ongoing pathophysiological process or hyperactivation [6,7]. Despite the number lot of clinical evidences about the involvement of EVs in physiological and pathophysiological processes, the role of EVs is not well established, and the mechanisms regulating EVs formation are still unrevealed and there are extensively investigated on in vivo and in vitro.

\section{Biological Role of EVs}

Recent studies have confirmed that EVs act as conveyors, which can horizontally transfer biologically active molecules(proteins, microRNA) participating in cell adhesion, chemotaxis and angiogenesis [6,8-10]. Our preliminary data showed that EVs isolated from patient plasma have both proangiogenic and anti-angiogenic characteristics in terms of their microRNA profile [8].

\section{Potential Therapeutic Application of EVs in} Regenerative Medicine

EVs from mesenchymal stem cells (MSC) showed the ability to alter the cell phenotype and function. For example, EVs derived from non-diabetic adipose tissue-derived mesenchymal stem cells (nAT-MSCs) improved migration and wound healing ability of diabetic MSC in vitro [11]. However, type 2 diabetic adipose tissue-derived mesenchymal stem cells (dAT-MSCs) increased cell aggregation and adhesion in vitro and impaired wound healing in vivo. Nevertheless, the mechanism how EVs from nAT-MSCs acts on cells remains unknown.

\section{Conclusion}

The contribution of EVs in the regenerative angiogenesis is depending on their microRNA cargo and their protein profile. The significant role of EVs as novel mediators, potential biomarkers and therapeutic targets in angiogenesis should be explored.

\section{Acknowledgement}

This study was supported by the Polish National Science Centre (NCN) the grant OPUS 4 for Ewa Stępień (2012/07/B/ NZ5/02510). The authors are grateful to Dr Eng. Olga Woźnicka from Department of Cell Biology and Imaging Institute of Zoology, Jagiellonian University for her kind help in TEM imaging and to Dr Marcin Libera Centre of Polymer and Carbon Materials, Polish Academy of Sciences (Zabrze, Poland) for his help in Cryo-TEM study.

\section{References}

1. Wolf $P$ (1967) The nature and significance of platelet products in human plasma. Br J Haematol 13(3): 269-288.

2. Farquhar MG, Palade GE (1960) Segregation of ferritin in glomerular protein absorption droplets. J Biophys Biochem Cytol 7(2): 297-304.

3. Trams EG, Lauter CJ, Salem N Jr, Heine U (1981) Exfoliation of membrane ecto-enzymes in the form of micro-vesicles. Biochim Biophys Acta 645(1): 63-70.

4. Cocucci E, Meldolesi J (2015) Ectosomes and exosomes: shedding the confusion between extracellular vesicles. Trends Cell Biol 25(6): 364372.

5. Kim DK, Lee J, Kim SR, Choi DS, Yoon YJ, et al. (2015) EVpedia: a community web portal for extracellular vesicles research. Bioinformatics 31(6): 933-939.

6. Tokarz A, Szuścik I, Kuśnierz-Cabala B, Kapusta M, Konkolewska M, et al. (2015) Extracellular vesicles participate in the transport of cytokines and angiogenic factors in diabetic patients with ocular complications. Folia Med Cracov 55(4): 35-48.

7. Stępień E, Stankiewicz E, Zalewski J, Godlewski J, Zmudka K, et al. (2012) Number of microparticles generated during acute myocardial infarction and stable angina correlates with platelet activation. Arch Med Res 43(1): 31-35.

8. Stępień E, Enguita FJ, Targosz-Korecka M, Nalepa A, Tylko G, et al. (2015) Analysis of miRNA cargo in plasma microvesicles in human plasma EuroMedLab Paris. ClinChem Lab Med 53(Special Suppl): S1S1450.

9. Alexandru N, Badila E, Weiss E, Cochior D, Stępień E, et al. (2016) Vascular complications in diabetes: Microparticles and microparticle associated microRNAs as active players. BiochemBiophys Res Commun 472(1): 1-10.

10. Kasprzyk J, Stępień E, Piekoszewski W (2017) Application of nanoLC-MALDI-TOF/TOF-MS for proteomic analysis of microvesicles. Clin Biochem 50(4-5): 241-243.

11. Trinh NT, Yamashita T, Tu TC, Kato T, Ohneda K, et al. (2016) Microvesicles enhance the mobility of human diabetic adipose tissuederived mesenchymal stem cells in vitro and improve wound healing in vivo. Biochem Biophys Res Commun 473(4): 1111-1118. 

(C) Commons Attribution 4.0 License DOI: 10.19080/CTBEB.2017.03.555602
Your next submission with Juniper Publishers will reach you the below assets

- Quality Editorial service

- Swift Peer Review

- Reprints availability

- E-prints Service

- Manuscript Podcast for convenient understanding

- Global attainment for your research

- Manuscript accessibility in different formats

( Pdf, E-pub, Full Text, Audio)

- Unceasing customer service

Track the below URL for one-step submission https://juniperpublishers.com/online-submission.php 